\title{
PTGDS Gene
}

National Cancer Institute

\section{Source}

National Cancer Institute. PT GDS Gene. NCI Thesaurus. Code C159265.

This gene is involved in synthesis of prostaglandin D2. 